\title{
APLIKASI ALJABAR MAKS-PLUS PADA JALUR TAKSI UNTUK MEMAKSIMUMKAN PENDAPATAN PENGEMUDI TAKSI
}

\author{
DORTEUS LODEWYIK RAHAKBAUW \\ Staf Jurusan Matematika FMIPA UNPATTI \\ J1. Ir. M. Putuhena, Kampus Unpatti, Poka-Ambon \\ e-mail: lodewyik@gmail.com
}

\begin{abstract}
ABSTRAK
Jaringan jalur transportasi pada suatu daerah memegang peranan penting dalam mobilitas masyarakat antar satu daerah, baik antar kota maupun antar tempat yang satu ke tempat yang lain. Berbagai macam alat transportasi digunakan baik alat transportasi umum maupun pribadi. Ditengah aktivitas yang padat masyarakat yang berekonomi menengah kebawah cenderung menggunakan taksi sebagai solusi untuk membantu aktivitas agar tepat waktu, ditengah kepadatan lalu lintas. Jalur taksi pada umumnya lebih bervariasi daripada jalur kendaraan umum karena tidak mempunyai jalur yang ditetapkan. Sopir taksi dalam hal ini cenderung memaksimalkan tarif/ongkos yang didapat untuk itu sering diambil jalur yang dapat memaksimalkan tarif/ongkos tersebut. Dalam paper ini dikonstruksikan model aljabar maksplus untuk rute/jalur taksi yang dianggap maksimal dan akan ditempuh oleh seorang pengemudi taksi.
\end{abstract}

Keywords: graph, jalur taksi, aljabar maks-plus, lintasan kritis

\section{PENDAHULUAN}

Transportasi menjadi alat yang sangat penting dalam mobilitas masyarakat ditengah aktivitasnya sehari-hari. Namun seringkali transportasi seringkali dikaitkan dengan ketepatan waktu yang harus dicapai oleh pengguna alat tranportasi.

Dalam paper ini penulis mencoba mengabaikan hal tersebut tetapi akan dikaji jalur taksi yang bisa menghasilkan pendapatan yang maksimal dari seorang pengemudi taksi.

Dengan mengabaikan waktu dan berorientasi pada tarif deterministi pada kajian jalur taksi, akan dikonstruksikan aljabar maks-plus untuk bagaimana pengemudi taksi dapat mencapai tujuan penumpang dengan memilih jalur-jalur yang dirasa sangat menguntungkannya.

\section{TINJAUAN PUSTAKA}

\section{Aljabar Maks-Plus}

Elemen dasar dari aljabar maks-plus adalah bilangan real dan $\varepsilon=-\infty$. Operasi dasar dari aljabar maks-plus adalah maximum (dinotasikan dengan simbol $\bigoplus$, “dibaca :
O-plus") dan tambah (dinotasikan dengan simbol $\bigotimes$, "dibaca O-times") dengan dua operasi tersebut diperoleh : $x \oplus y=\operatorname{maks}(x, y)$ dan $x \oplus y=x+y$

Untuk setiap $x, y \in \mathbb{R}$, dimana $\mathbb{R}_{\varepsilon}=\mathbb{R} \cup\{\varepsilon\}$. Catatan: $\quad x \oplus \varepsilon=x=\varepsilon \oplus x$ untuk semua $x \in \mathbb{R}_{\varepsilon}$. Operasi $\bigoplus$ dan $\otimes$ yang diperluas ke matriks sebagai berikut :

dan

$$
(A \oplus B)_{i, j}=a_{i, j} \oplus b_{k, j}=\operatorname{maks}\left(a_{i, j}, b_{k, j}\right)
$$

$$
(A \otimes B)_{i, j}=\bigoplus_{k} a_{i, j} \otimes b_{k, j}=\operatorname{maks}_{k}\left(a_{i, j}, b_{k, j}\right)
$$

untuk semua $i, j$.

\section{Definisi Graph Dalam Aljabar Max-Plus}

- Diberikan graph berarah $G=(V, A)$ dengan $V$ adalah suatu himpunan berhingga tak kosong yang anggotanya disebut titik (vertex) dan $A$ adalah suatu himpunan pasangan terurut titik-titik pada garis (edge) V.

- Suatu barisan garis dari $\left(i_{1}, i_{2}\right),\left(i_{2}, i_{3}\right), \cdots,\left(i_{l-1}, i_{1}\right)$ dari suatu garis dinamakan path.

- Suatu path dikatakan elementer apabila tidak ada titik terjadi dua kali dalam path tersebut.

- Suatu sirkuit adalah path elementer tertutup yaitu $\left(i_{1}, i_{2}\right),\left(i_{2}, i_{3}\right), \cdots,\left(i_{l-1}, i_{1}\right)$. 
- Suatu graph berarah $G=(V, A)$ dengan $V=$ $\{1,2, \ldots, n\}$ dikatakan strongly connected jika untuk setiap $i, j \in V, i \neq j$, terdapat suatu lintasan dari $i$ ke $j$. Suatu graph yang memuat sirkuit disebut graph siklik, sedangkan suatu graph yang tidak memuat sirkuit disebut graph tak siklik.

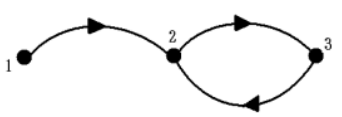

(a)

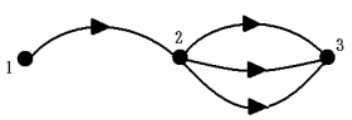

(b)
Gambar 1. (a) merupakan path elementer,gambar (b) bukan path elementer

- Graph berarah $\mathrm{G}$ dikatakan berbobot jika setiap garis $(j, i) \in A$ dikawankan dengan suatu bilangan real $A_{i j}$. Bilangan real $A_{i j}$ disebut bobot garis $(j, i)$, dilambangkan dengan $\mathrm{w}(\mathrm{j}, \mathrm{i})$. Graph preseden dari matriks $\mathrm{A} \in R_{\max }^{n x n}$ adalah graph berarah berbobot $\mathrm{G}(\mathrm{A})=(\mathrm{V}, \mathrm{A})$ dengan $\mathrm{V}=\{1,2, \ldots, \mathrm{n}\}, \mathrm{A}=\{(\mathrm{j}, \mathrm{i}) \mid$ $\left.\mathrm{w}(\mathrm{i}, \mathrm{j})=\mathrm{A}_{\mathrm{ij}} \neq \varepsilon, \square \forall \mathrm{i}, \mathrm{j}\right\}$. Sebaliknya untuk setiap graph berarah berbobot $\mathrm{G}=(\mathrm{V}, \mathrm{A})$ selalu dapat didefinisikan suatu matriks $\mathrm{A} \in R_{\max }^{n x n}$ dengan $\mathrm{A}_{\mathrm{ij}}=$ $\left\{\begin{array}{l}w_{i j}, \quad j i k a(i, j) \in A \\ \varepsilon, \quad j i k a(i, j) \in \neq A\end{array}\right.$, yang disebut matriks bobot graph $\mathrm{G}$.

- Bobot suatu path $P=\left(i_{1}, i_{2}\right),\left(i_{2}, i_{3}\right), \cdots,\left(i_{l-1}, i_{1}\right)$ dinotasikan oleh $|P|_{w}$ dan diberikan oleh:

$$
\begin{array}{rl}
P=w\left(i_{1}, i_{2}\right)+w & w\left(i_{2}, i_{3}\right)+\cdots+w\left(i_{l-1}, i_{1}\right) \\
& =\left(a_{i_{2}, i_{1}}+a_{i_{3}, i_{2}}+\cdots+a_{i_{1}, i_{l-1}}\right)
\end{array}
$$

- Panjang dari path $\mathrm{P} /$ banyak garis dalam path $\mathrm{P}$ dinotasikan oleh $|P|_{l}$

- Bobot rata-rata dari path $\mathrm{P}$ adalah bobot $\mathrm{P}$ dibagi banyak garis dalam path $\mathrm{P}$ :

$$
\frac{|P|_{w}}{|P|_{l}}=\frac{a_{i_{2}, i_{1}}+a_{i_{3}, i_{2}}+\cdots+a_{i_{1}, i_{l-1}}}{(l-1)}
$$

\section{HASIL DAN PEMBAHASAN}

\section{Pemodelan Jaringan Transportasi (Jalur Taksi)}

\section{a. Asumsi pendukung.}

Diasumsikan bahwa walaupun penumpang taksi cenderung berkeinginan sampai tepat pada waktunya namun pengemudi taksi selalu memperhitungkan biaya yang nantinya dia terima, sehingga pengemudi taksi akan mengambil jalur yang dirasanya dapat mencapai ongkos/tarif maksimum. Dengan kata lain pengemudi taksi yang menentukkan jalur/rute untuk dicapai ke tempat tujuan penumpang.

Dalam kenyataannya seringkali terdapat faktorfaktor pendukung seorang pengemudi taksi mendapatkan tarif/biaya maksimum seperti waktu tunggu saat berada pada lampu lalu lintas, waktu tunggu pada saat terjadi kemacetan, kecepatan taksi yang diatur oleh pengemudi taksi, lama perjalanan dan sebagainya.
Dan sebaliknya faktor-faktor yang kurang mendukung adalah permintaan rute oleh penumpang kepada pengemudi taksi yang dapat meminimumkan pendapatan pengemudi taksi tersebut

Dalam paper ini dikaji sebuah contoh jalur taksi dengan ongkos/tarif deterministik yang sudah ditentukan

Tabel 1. Jalur dan biaya taksi

\begin{tabular}{|l|c|c|c|}
\hline Kode & dari & Tujuan & $\begin{array}{c}\text { Tarif } \\
\text { (puluh ribu) } \\
\text { Rupiah }\end{array}$ \\
\hline 1 & K1 & K1 & 5 \\
\hline 2 & & A & 3 \\
\hline 3 & & A & 4 \\
\hline 4 & & K2 & 0 \\
\hline 5 & & K3 & 7 \\
\hline 6 & K2 & K1 & 0 \\
\hline 7 & & A & 4 \\
\hline 8 & & K2 & 1 \\
\hline 9 & & K3 & 0 \\
\hline 10 & K3 & K1 & 0 \\
\hline 11 & & A & 2 \\
\hline 12 & & K2 & 6 \\
\hline 13 & & K3 & 2 \\
\hline 14 & A & K1 & 4 \\
\hline 15 & & K2 & 6 \\
\hline 16 & & K3 & 3 \\
\hline
\end{tabular}

\section{b. Contoh jalur taksi}

Pada bagian ini akan dikaji jalur taksi yang digunakan oleh seorang pengemudi taksi dalam memaksimalkan pendapatan yang didapat. Dalam contoh ini dibuat graph berarah (directed graph), dimana ada 4 node yang menunjukkan tempat yakni kota $1\left(\mathrm{~K}_{1}\right)$, kota $2\left(\mathrm{~K}_{2}\right)$, kota $3\left(\mathrm{~K}_{3}\right)$, dan pelabuhan udara $($ Airport $)(\mathrm{A})$, dimana bobot-bobot dari masing-masing garis(edge) menunjukkan tarif/ongkos rute.

Dari Tabel 1 terlihat pada kode 2, dan 3 terdapat jalur yang sama untuk itu pengemudi akan selalu memakai jalur yang dirasanya maksimum terhadap tarif/ongkos.

$$
2 \oplus 3=\operatorname{maks}(3,4)=4
$$

Dengan demikian jalur dari kode 2 akan selalu diabaikan oleh pengemudi taksi dan juga jalur dari kode 4, 6, 9, 10 karena menghasilkan tarif yang minimum

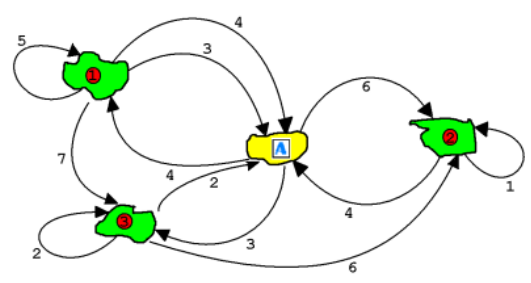

Gambar 2

Graph di atas diubah menjadi graph seperti di bawah ini karena diambil maksimum dari path yang sama. 


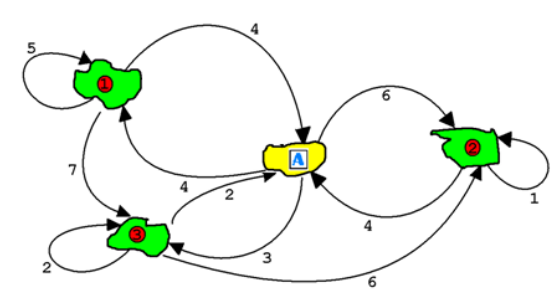

Gambar 3

Graph berarah yang dibangun berdasarkan jalur taksi yang diberikan pada tabel

Dari graph diatas didapat matriks bobot sebagai berikut :

$$
\begin{aligned}
& \begin{array}{llll}
k_{1} & a & k_{2} & k_{3}
\end{array}
\end{aligned}
$$

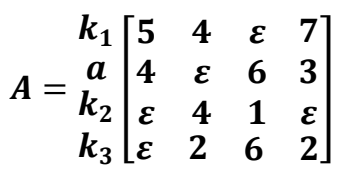

Berdasarkan graph di atas dapat dibuat path berdasarkan kode sebagai berikut : 1, 3, 5, 7, 8, 11, 12, 13, 14, 15, dan 16

\section{Kajian Aljabar Maks-Plus dengan menggunakan Scilab}

a. Menentukan Maximum Cycle Mean (MCM)

Diketahui ada 13 jalur sikel/sirkuit, dan secara manual didapat :

Tabel 2

\begin{tabular}{|l|l|l|}
\hline No & \multicolumn{1}{|c|}{$\begin{array}{c}\text { JALUR } \\
\text { SIRKUIT }\end{array}$} & \multicolumn{1}{|c|}{ CYCLE MEAN } \\
\hline 1 & K1-K1 & $5 / 1=5$ \\
\hline 2 & K1-A-K1 & $(4 \otimes 4) / 2=4$ \\
\hline 3 & K1-K3-A-K1 & $(7 \otimes 2 \otimes 4) / 3=4,33 \ldots$ \\
\hline 4 & K1-K3-K2-A-K1 & $(7 \otimes 6 \otimes 4 \otimes 4) / 4=5,25$ \\
\hline 5 & K2-K2 & $1 / 1=1$ \\
\hline 6 & K2-A-K2 & $(6 \otimes 4) / 2=5$ \\
\hline 7 & K2-A-K3-K2 & $(4 \otimes 3 \otimes 6) / 3=4,33 \ldots$ \\
\hline 8 & K2-A-K1-K3-K2 & $(4 \otimes 4 \otimes 7 \otimes 6) / 4=5,25$ \\
\hline 9 & K3-K3 & $3 / 1=3$ \\
\hline 10 & K3-A-K3 & $(2 \otimes 3) / 2=2,5$ \\
\hline 11 & K3-A-K1-K3 & $(2 \otimes 4 \otimes 7) / 3=4,33 \ldots$ \\
\hline 12 & K3-K2-A-K3 & $(6 \otimes 4 \otimes 3) / 3=4,33 \ldots$ \\
\hline 13 & K3-K2-A-K1-K3 & $(6 \otimes 4 \otimes 4 \otimes 7) / 4=5,25$ \\
\hline
\end{tabular}

Pada dasarnya no. 3 dan 11 adalah bentuk sikel yang sama (misalkan sikel a), no. 4, 8, dan 13 juga sama (misalkan sikel b), no.7 dan 12 juga sama (misalkan sikel c), ditambah 1, 2, 5, 6, 9, 10 jadi ada 9 bentuk sikel/sirkuit. Dan Maximum Cycle Mean (MCM) dari 9 bentuk sikel/sirkuit adalah $(a \oplus b \oplus c \oplus 1 \oplus 2 \oplus 5 \oplus 6 \oplus 9 \oplus 10)$

$$
=\operatorname{maks}(a, b, c, 1,2,5,6,9,10)
$$

$$
\begin{aligned}
& =\operatorname{maks}(4.33,5.25,4.33,5,4,1,5,3,10) \\
& =5.25
\end{aligned}
$$

Dengan menggunakan scilab :

$-->\mathrm{t}=-\%$ inf

$\mathrm{t}=$

-Inf

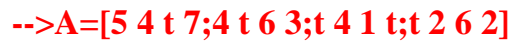

$\mathrm{A}=$

5. 4. $-\operatorname{Inf} 7$.

4. - Inf 6.3.

-Inf 4. 1. -Inf

-Inf 2. 6. 2.

$-->\operatorname{mcm}=$ maxplusmcm(A)

$\mathrm{mcm}=$

5.25

\section{b. Lintasan kritis}

Menentukan lintasan kritis adalah hal yang sangat penting bagi seorang pengemudi taksi, karena pada lintasan kritis tersebut akan dipakai sebagai jalur yang akan sering digunakkan oleh pengemudi taksi.

Dengan mendapatkan maksimum dari semua sikel mean (maximum cycle mean), akan didapat rute yang menyebabkan tarif tersebut dalam hal ini bobot pada graph A menjadi maksimum.

Hal ini mengandung arti bahwa pada sikel tersebut pengemudi taksi dapat memaksimalkan tarif yang dicapai yakni sebesar 210.000 yakni no 4, 8 dan 13 yang menunjukkan rute masing-masing K1-K3-K2-AK1, untuk berangkat dari kota 1; K2-A-K1-K3-K2, untuk berangkat dari kota 2, K3-K2-A-K1-K3 untuk berangkat dari kota 3.

Berikut implementasi dengan scilab dalam hal menentukan lintasan kritis.

$-->[1, \mathrm{~d}, \mathrm{x}]=\operatorname{maxplusccir}(\mathrm{A})$

$\mathrm{x}=$

1. 4. 3. 2 .

$\mathrm{d}=$

4.

$1=$

5.25

c. Strongly connected

Untuk mengecek apakah graph A ini strongly connected ataukah tidak maka dengan menggunakan tool yang ada pada scilab.

$\mathrm{S}=\operatorname{maxplusscg}(\mathrm{A})$

$\mathrm{s}=$

$\mathrm{T}$

Didapat jawaban T yang berarti benar (True), hal ini berarti graph berarah A yang merupakan konstruksi graph atas jalur/rute taksi adalah strongly connected.

\section{KESIMPULAN}

Kesimpulan yang dapat di capai adalah :

Untuk memaksimalkan pendapatan pengemudi taksi dalam hal ini tarif/ongkos dari penumpang harus beroperasi pada lintasan kritis dalam hal ini maksimum dari sikel-sikel mean yang ada (maximum cycle mean). 
Selanjutnya paper ini dapat disempurnakan dengan menggunakan maks-min untuk mendapatkan waktu yang minimum bagi keuntungan penumpang.

\section{DAFTAR PUSTAKA}

St'ephane Gaubert and Max Plus, Methods and Applications of $(\max ,+)$ Linear Algebra, INRIA, Domaine de Voluceau, BP105, 78153 Le Chesnay Cedex, France.

ftp://ftp.inria.fr/INRIA/publication/publipdf/RR/RR-3088.pdf

Winarni, dan Subiono, Penjadwalan jalur bus dalam kota dengan aljabar max-plus, Seminar nasional matematika IV , Institut teknologi sepuluh nopember surabaya, 13 desember 2008

Subiono, (2000), On classes of min-max-plus systems and their application, Thesis Ph.D., Technische Universiteit Delft, Delft. 